\title{
ANALYSIS OF RELAXATION OF VARISTOR-POSISTOR VOLTAGE LIMITING DEVICE IN PHOTOVOLTAIC MODULES DURING RENEWAL OF LIGHTING
}

\author{
A.S. Tonkoshkur, A.V. Ivanchenko* \\ Oles Honchar Dnipro National University, Dnipro, Ukraine \\ e-mail: IvanchenkoAV@ukr.net
}

\begin{abstract}
The features of the operation of the circuit method based on a structure of a varistor-PPTC fuse type being in thermal contact to protect the photovoltaic cells from overvoltages arising from the partial shading of the photovoltaic modules of solar arrays are considered. The conditions for the relaxation of the functional characteristics of such voltage limiting devices to the initial state which does not affect the operation of the photovoltaic module during renewal of lighting of the photovoltaic cells are analyzed. It is established that the temperature and resistance dependences of the PPTC element, which determine its state, have a relaxation character at small values of such parameters of the voltage limiting device as the passport values of the resistance of the PPTC element in the conducting ("cold") state and thermal resistance of the voltage limiting device. The relaxation time is of the order of a few seconds. For large values of the indicated parameters, a situation may occur when such relaxation is absent and the voltage limiting device maintains an active low-conductive ("hot") state.

Keywords: photovoltaic cell, varistor ceramics, PPTC fuse, voltage limiting device, relaxation characteristic, thermal resistance.
\end{abstract}

Received 09.11.2019; Received in revised form 10.12.2019; Accepted 23.12.2019

\section{Introduction}

The photovoltaic module consists of series-connected photovoltaic cells that are divided into several submodules [1-3]. Each such submodule is equipped with a bypass diode, which is connected in parallel with it. If one or several photovoltaic cells reduce the photocurrent generated by them due to a malfunction or shadowing, then the current from other submodules flows through the bypass diode, and the considered submodule with a shaded photovoltaic cells is in a short circuit state. The lighting cells inside the submodule cannot transfer their generated photocurrents to the external electrical circuit, because the series connection contains a big resistance created by the shaded cells. The voltage created by these photovoltaic cells shifts the p-n junction of the shaded element in the reverse direction, and it works as a load, and not as a generator. Energy dissipation at the indicated load leads to inhomogeneous heating of the module, in particular, to the appearance of local heating regions in it, which are called "hot spots" [4, 5].

Among the circuitry means for protecting photovoltaic cells of solar arrays from overvoltage, one of the new approaches is the use of voltage limiting devices based on a structure of two electrically series-connected layers. One of these layers is varistor ceramics, and the second one is a nanocomposite used in PPTS fuses of the "PolySwitch" technology; the layers are in thermal contact [6]. The input voltage of such a voltage limiting devices $U_{\text {in }}$ is applied to the series connection of the varistor and posistor elements, and the output voltage $U_{\text {out }}$ is removed from the varistor layer [7, 8].

One or a group of series-connected photovoltaic cells is connected to the varistor layer (output circuit) of a separate voltage limiting device. Serial connection of voltage limiting devices form a submodule of a photovoltaic module with a bypass diode connected in parallel to it. When an input overvoltage is applied to such a voltage limiting device, the heat dissipated by the varistor layer heats the posistor layer and causes an increase in its resistance. As a result, there is a redistribution of the input overvoltage between the layers, which, in the end, can provide a limitation of the output voltage removed from the varistor layer at a given level. This voltage is applied to the load connected in parallel to the varistor 
layer.

For the prospective implementation of the considered method of protecting photovoltaic cells from overvoltages, analysis of the functioning process of the considered varistor-posistor device in photovoltaic modules $\mathrm{f}$ solar arrays is necessary. One of the most important and insufficiently investigated modes of operation of such a device is its behavior when the submodule of the module returns from a partially shaded state to a lighted one.

The results of a study of the operation of a varistor-posistor voltage limiting device in a state of relaxation during the renewal of lighting, obtained using mathematical modeling, are presented in this paper.

\section{Physical concepts}

When submodule of the photovoltaic module returning from partially shaded in a fully lighted state the transition of the resettable fuse to a highly conductive ("cold") state can occur only when its temperature decreases due to a decrease in the supplied electric power. The initial stage of this process is illustrated in Fig. 1. When the submodule of the photovoltaic module is fully lighted, the varistor resistance becomes large (shown by an open switch) due to the fact that a small voltage is applied to it. This voltage is generated by one photovoltaic cell (or one section of the photovoltaic cells) and it is less than the classification voltage of the varistor. The thermal power dissipated by the varistor becomes insufficient to maintain the resettable fuse at the tripping temperature. As a result, the temperature of the resettable fuse decreases and its resistance decreases.

In the analyzed situation, the current through the voltage limiting device $I$ should be less than the value of the tripping current of the resettable fuse element $I_{\text {trip }}$ at the actual temperature of the posistor layer.

\section{Modeling of relaxation process}

The heat balance equation for the posistor layer, which describes such a process of relaxation of the voltage limiting device, can be written as

$$
C \frac{d T(t)}{d t}=P_{P P T C}[E, T(t)]-\frac{T(t)-T_{0}}{R T} ; \quad T(t=0)=T_{\text {trip }}
$$

where

$$
P_{P P T C}[E, T]=\frac{R_{F u}(T)}{R_{F u}(T)+R_{s}} \cdot \frac{E}{R_{F u}(T)+R_{s}} \cdot E ;
$$

$T=T(t)$ and $T_{0}$ are the PPTC fuse temperature and the ambient temperature; $t$ is time; $R_{F u}(T)=$ const $/\left(T_{\text {trip }}-T\right)$ is the approximation of the temperature dependence of the PPTC fuse; const $=R_{F u 0}\left(T_{\text {trip }}-T_{0}\right)$ at $T_{0}=298 \mathrm{~K} ; R_{F u 0}$ is the value of fuse resistance in a conducting state [3];E=K.M.U and $R_{s}=K \cdot M \cdot r_{s}$ are the electrical voltage generated by the photovoltaic submodule with relaxing voltage limiting device and the electrical resistance of the photovoltaic submodule; $U$ and $r_{s}$ are the voltage generated by a separate photovoltaic cell and its equivalent series electrical resistance [9]; $K$ and $M$ are the number of photovoltaic cells in the section and the number of sections in the submodule; $C$ and $R T$ are the thermal capacity and thermal resistance of the voltage limiting device;

Typical values of the parameters of photovoltaic cells with a generation current of 2 A based on monocrystalline silicon $U=0.56 \mathrm{~V} ; r_{s}=0.04 \mathrm{Ohm}$ were used in numerical experiments. It was taken $K=1 ; M=60$. 


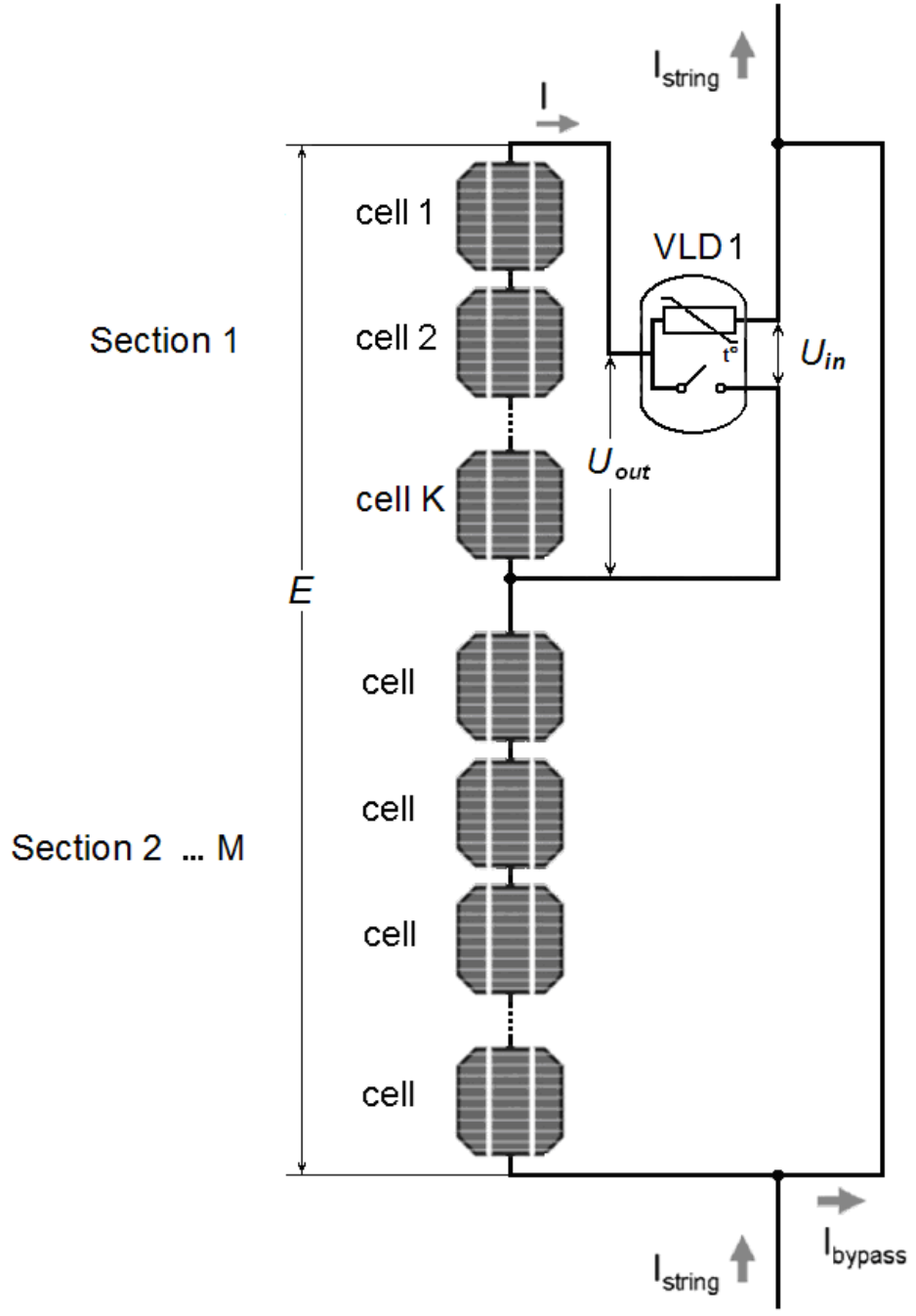

Fig. 1. Equivalent circuit illustrating the state of the voltage limiting device $V L D 1$ at the initial moment of relaxation after the renewal of the lighting state.

$I_{\text {string }}, I_{\text {bypass }}$ and $I$ are the current coming from other submodules, the current through the bypass diode and the leakage current through the heated posistor layer of the voltage limiting device.

As follows from equation (1) for the relaxation mode of the varistor-posistor voltage limiting device under consideration, the main parameters that can be selected are thermal resistance of the voltage limiting device $R T$ and electrical resistance in the conducting ("cold") state of the posistor element $R_{F u 0}$.

Typical relaxation dependences of the temperature of the voltage limiting device $T(t)$ and the electrical resistance of the posistor element of the voltage limiting device $R_{F u}(t)$ are presented in Fig. 2 and Fig. 3. As you can see, the previously mentioned parameters of the voltage limiting device also have a significant effect on these dependencies.

Relaxation of temperature and electrical resistance to their initial values (corresponding to the "cold" highly conductive state of the posistor) is possible only for 
voltage limiting devices that have small values of thermal resistance of the voltage limiting device $R T$ (Fig. 2, curves 1, 2, 3).

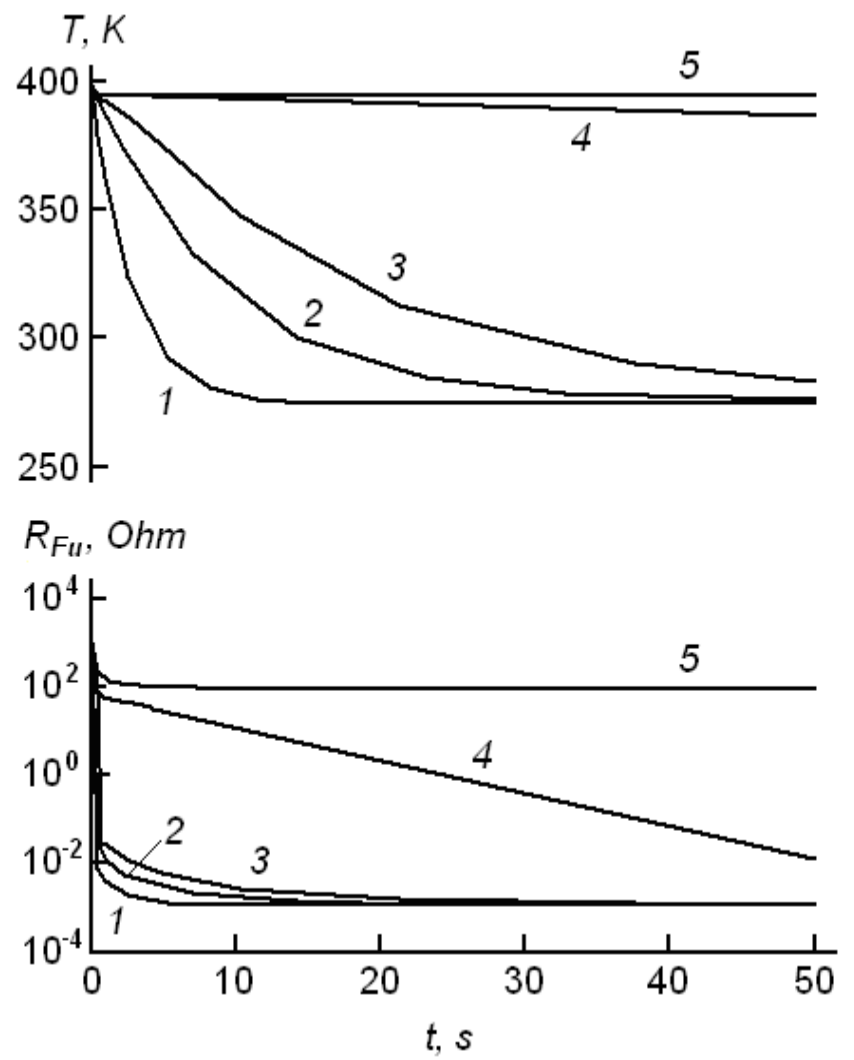

Fig. 2. Dependences of the temperature $T$ and the electrical resistance of the PPTC fuse layer of the voltage limiting device $R_{F u}$ on the relaxation time $t$ after the previously shaded photovoltaic cell returns to the lighted state when using the PPTC layer fuse with electrical resistance in the conducting state $R_{F u 0}=0.001 \mathrm{Ohm}$ and the voltage limiting device with thermal resistance $R T, \mathrm{~K} / \mathrm{W}$ : $1-5 ; 2-15 ; 3-27 ; 4-40 ; 5-60$.

Relaxation is not observed at large values of this parameter. The length of the relaxation time interval does not exceed several seconds and it decreases with decreasing thermal resistance of the voltage limiting device.

Similar patterns were found when studying the influence of the parameter of the posistor element $R_{F u}$ on the form of the analyzed relaxation dependences (Fig. 3).

The relaxation of temperature and electrical resistance to their initial values is observed only for voltage limiting devices, which have small values of the electrical resistance of the posistor layer in the conducting state $R_{F u 0}$ (curves 1 and 2). The relaxation time is $1 \ldots 3$ seconds. The voltage limiting device is in a stationary lowconductive state at high values of the $R_{F u}$ (curves 3 and 4 ). In this case (as in the presence of large thermal resistances of the voltage limiting device $R T$ ), the transfer of a resettable fuse from a low-conductive state to a high-conductive can occur when the entire submodule of the photovoltaic cells is obscured, that corresponds to the cessation of the process of electric energy photogeneration by it or de-energization. 


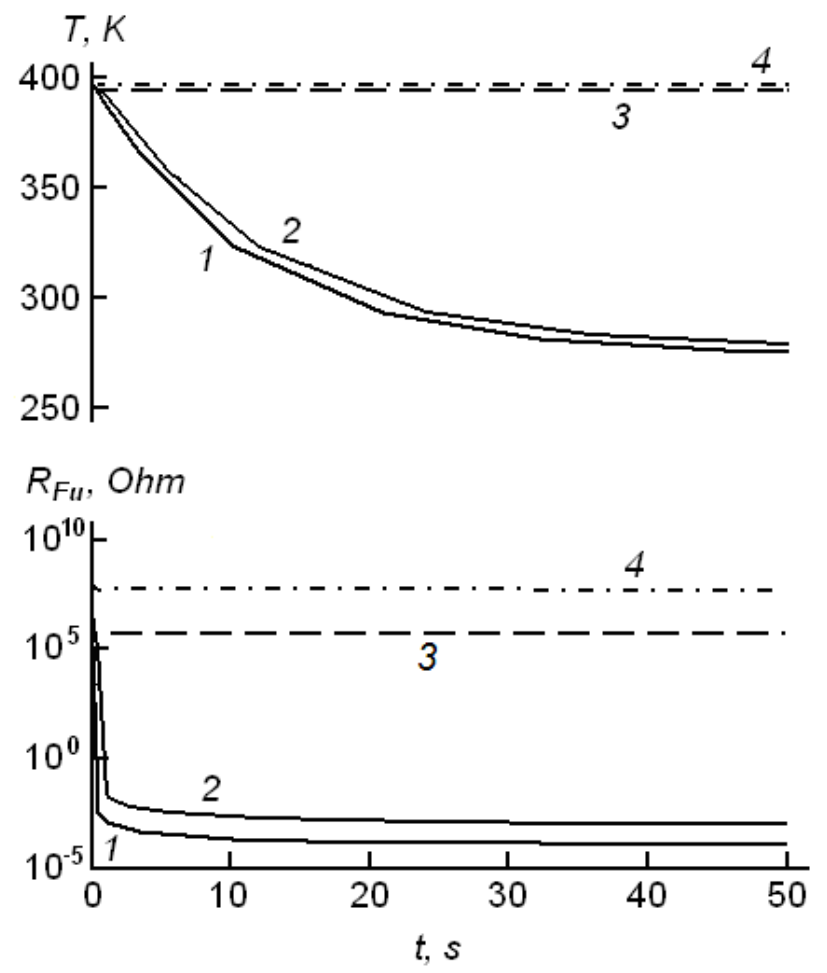

Fig. 3. Dependences of the temperature $T$ and the electrical resistance of the PPTC fuse layer of the voltage limiting device $R_{F u}$ on the relaxation time $t$ after the previously shaded photovoltaic cell returns to the lighted state when using the voltage limiting device with thermal resistance $R T=20 \mathrm{~K} / \mathrm{W}$ and the PPTC layer fuse with electrical resistance in the conducting state $R_{F u 0}$, Ohm: $1-0.0001 ; 2-0.001 ; 3-0.01 ; 4-0.1$.

\section{Conclusions}

The analysis of the behavior of voltage limiting devices of the varistor-PPTC fuse type being in thermal contact in photovoltaic modules when resuming lighting is carried out. The conditions for the relaxation of such voltage limiting devices to the initial state, which does not affect the operation of the photovoltaic module, are determined.

A significant influence of such parameters of the voltage limiting devices as the resistance of the PPTC fuse in the conducting state $R_{F u 0}$ and the thermal resistance of the voltage limiting device $R T$ on the form of relaxation characteristics is established.

Dependences of temperature and electrical resistance, which determine the state of the voltage limiting device, on time have a relaxation character at small values of the indicated parameters $\left(R_{F u 0}<10^{-3} \mathrm{Ohm}\right.$ and $R T<30 \mathrm{~K} / \mathrm{W}$ for the taken characteristics of the photovoltaic cell). Relaxation time is about a few seconds.

With relatively large values of these parameters, a situation may occur when such relaxation is absent and the PPTC fuse of the voltage limiting device maintains a lowconductive ("hot") state.

\section{References}

1. D'Alessandro, V. A straightforward method to extract the shunt resistance of photovoltaic cells from current-voltage characteristics of mounted arrays / 
V. d'Alessandro, P. Guerriero, S. Daliento, M. Gargiulo // Solid-State Electronics. 2011. - Vol. 63, Iss. 1. - P. $130-136$.

2. Chen, K. Study of crystalline silicon solar cells with integrated bypass diodes / K. Chen, D. Chen, Y. Zhu, H. Shen // Science China Technological Sciences. - 2012. Vol. 55, Iss. 3. - P. $594-599$.

3. Khaing, H.H. Characteristics of different solar PV modules under partial shading / H.H. Khaing, Y.J. Liang, N.N.M. Htay, J. Fan // World Academy of Science, Engineering and Technology. International Journal of Energy and Power Engineering. 2014. - Vol. 8, No. 9. - P. 1418 - 1422.

4. Daliento, S. A modified bypass circuit for improved hot spot reliability of solar panels subject to partial shading / S. Daliento, F. Di Napoli, P. Guerriero, V. d'Alessandro // Solar Energy. - 2016. - Vol. 134. - P. 211 - 218.

5. Tonkoshkur, O.S. Problemy nadiinosti fotoelektrychnykh komponentiv soniachnykh batarei / O.S. Tonkoshkur, L.V. Nakashydze // Vidnovliuvana enerhetyka. 2018. - No. 3. - P. $21-31$.

6. Tonkoshkur, O.S. Skhemotekhnichni tekhnolohii pidvyshchennia nadiinosti vidnovliuvanykh dzherel enerhii na osnovi soniachnykh batarei $\mathrm{z}$ vykorystanniam elementiv funktsionalnoi elektroniky / O.S. Tonkoshkur // Materialy VII Mizhnarodnoi naukovo-praktychnoi konferentsii "Rozvytok biznes-analityky, obliku ta opodatkuvannia v umovakh hlobalizatsii, zahostrennia enerhetychnykh problem". - Ukraine, Dnipro. 2019. - P. $210-212$.

7. Golubovic, B. US Patent 7660096 B2 USA. Circuit protection device having thermally coupled MOV overvoltage element and PPTC overcurrent element / B. Golubovic, P.N. Becker, R.P. Moore. - 9.02.10.

8. Tonkoshkur, A.S. Electrical properties of structures based on varistor ceramics and polymer nanocomposites with carbon filler / A.S. Tonkoshkur, A.V. Ivanchenko // Journal of Advanced Dielectrics. - 2019. - Vol. 9, No. 3. - P. 1950023-1 - 1950023-6.

9. Humada, A. M. Solar cell parameters extraction based on single and doublediode models: A review / A.M. Humada, M. Hojabri, S. Mekhilef, H.M. Hamada // Renewable and Sustainable Energy Reviews. - 2016. - Vol. 56, - P. 494 - 509. 